University of Nebraska - Lincoln

DigitalCommons@University of Nebraska - Lincoln

2008

Beyond Liberals and Conservatives to Political Genotypes and Phenotypes

John R. Alford

Rice University

Carolyn L. Funk

Virginia Commonwealth University

John R. Hibbing

University of Nebraska-Lincoln, jhibbing1@unl.edu

Follow this and additional works at: https://digitalcommons.unl.edu/poliscifacpub

Part of the Political Science Commons

Alford, John R.; Funk, Carolyn L.; and Hibbing, John R., "Beyond Liberals and Conservatives to Political Genotypes and Phenotypes" (2008). Faculty Publications: Political Science. 31.

https://digitalcommons.unl.edu/poliscifacpub/31

This Article is brought to you for free and open access by the Political Science, Department of at DigitalCommons@University of Nebraska - Lincoln. It has been accepted for inclusion in Faculty Publications: Political Science by an authorized administrator of DigitalCommons@University of Nebraska - Lincoln. 


\title{
Beyond Liberals and Conservatives to Political Genotypes and Phenotypes
}

\author{
John R. Alford, Carolyn L. Funk, and John R. Hibbing
}

\begin{abstract}
In the past, most political scientists have been oblivious to the growing empirical evidence challenging environmental determinism. Professor Charney, apparently as a result of the fact that genes and the environment interact in a complex fashion, advocates that this passive unawareness be replaced by active denial. Science, however, does not advance by avoiding important relationships merely because they are complicated and, fortunately, science is not heeding Charney's ideologically-based fears. Molecular geneticists, often working in tandem with political scientists, are quickly moving beyond twin studies to identify the specific suites of genes and biological systems that predict variation in core political preferences, whatever labels those preferences might be given in a particular culture at a particular time. We sympathize with the fact that our empirical findings, like those of so many behavioral geneticists, make Charney uncomfortable; still, his critique serves up nothing new-empirically or otherwise. Just as analyses of the roots of sexual preferences cannot presumptively ignore genetics, neither can analyses of the roots of political preferences.
\end{abstract}

N/ ind-body dualism allows that the physical body is the product of natural, presumably genetic forces but insists that the source of the human mind is mystical and fundamentally different. The mind is not nature's but our own creation, shaped as we navigate and are influenced by historical and cultural realities that we have constructed. The human mind, dualism asserts, unlike all other aspects of life on our planet, transcends crude biological processes. And what better example of a pristine experiential, non-biological, uniquely-human phenomenon than mass-scale politics with its relatively recent advent and its constantly changing issues, terms, parties, and players. For those caught in the hubris of this dualist perspective, empirical evidence indicating that political orientations are transmitted genetically as well as culturally seems patently "incoherent" and must be the product of a flawed methodology.

Thus it is that Evan Charney rises to attack a recent article of ours in the American Political Science Review, ${ }^{1}$ an article he fears is part of "a trend among behavioral scientists to view ever more complex attitudes as in some sense genetically determined." ${ }^{2}$ We welcome the appearance of Charney's essay. The scientific process needs scholars eager to question methodologies, data, interpretations,

John R. Alford is Associate Professor of Political Science, RiceUniversity (jra@rice.edu). Carolyn L.Funk is Associate Professor of Political Science, Virginia Commonwealth University(clfunk@vcu.edu).John R. Hibbing is the Foundation Regents Professor of Political Science, University of Nebraska-Lincoln (jbibbing@unl.edu) and implications. Genetics in general and twin studies in particular are not familiar topics to most political scientists. Several of the misconceptions evident in Charney's written remarks are undoubtedly held by other members of the discipline so we are pleased to have been offered the opportunity to explain our procedures, findings, and conclusions more fully. Charney's criticisms fall into two broad categories. The first is that the methods we employed to obtain our results — specifically, the classical twin design rest on faulty assumptions and therefore yield meaningless results. The second, drawing directly from a dualist perspective, is that political beliefs are entirely embedded in culture and therefore, logically could not have a genetic component. We address each of these charges in turn. Our central point is that it is insufficient merely to assert the implausibility of political ideology being partially heritable; ultimately this matter can and must be decided by the scientific process.

\section{The Methodical Challenge}

Much of Charney's methodological critique centers on what has come to be termed the "equal environments assumption" (EEA). Monozygotic (MZ) twins share 100 percent of their genetic heritage while dizygotic (DZ) twins, like all full siblings, share roughly 50 percent. This known difference in genetic similarity across the two types of twins provides an opportunity to estimate the importance of genetic similarity - but only if the environments of $M Z$ and $\mathrm{DZ}$ twins are equally similar. If, relative to $\mathrm{DZ}$ twins, $M Z$ twins not only share more of their genetic code but also share more of their environmental experiences, variance attributed to genetics may actually be the result of 
environmental forces. Thus, the key concern is that heritability estimates will be inflated while the effect of shared environment will be underestimated.

The equal environments assumption is an important concern and Charney is quite right to raise it, but the EEA has been the subject of a tremendous amount of debate and research and Charney does not provide a fair assessment of current wisdom in the behavioral genetics literature. We have space to offer only a few corrections. One misconception springs from Charney's treatment of the environment as exogenous even as such a practice is invalidated by his own argument. Charney invokes a comment from Horwitz et al. pointing out that "because monozygotic twins have greater physical resemblance to each other than dizygotic twins, they could have a greater chance of receiving similar social reactions." ${ }^{3}$ If, as Charney and Horwitz believe, genes shape physical traits that in turn shape social reactions that in turn shape beliefs, the linkage structure is complete and genes will affect beliefs. Whether the causal order is [genes $\rightarrow$ beliefs] or [genes $\rightarrow$ physical traits $\rightarrow$ social reactions $\rightarrow$ beliefs], the underlying cause is still genetic. An example of the endogeneity of environmental forces is provided by O'Connor et al. who report that adoptive children genetically at risk for antisocial behavior are significantly more likely than not-atgenetic risk adoptive children to be the recipient of negative parenting from their adoptive parents. ${ }^{4}$ Negative parenting is typically assumed to be the cause of children's antisocial behavior but in point of fact children play an important role in shaping their own environment, in this case by influencing the behavior of their parents.

Even if we pretend genes have nothing to do with shaping the environment, the EEA withstands analysis. A surprising number of the parents of twins, as many as 20-30 percent in some studies, mis-categorize the zygosity of their twins, thus creating a valuable opportunity to distinguish environmental from genetic influences. If Charney is correct, the determining factor in twin pairs' degree of similarity should be their perceived zygosity; if we are correct, the determining factor in degree of similarity should be their actual zygosity. The results of these mis-categorization studies are clear: $\mathrm{DZ}$ twin pairs believed by their environments to be $\mathrm{MZ}$ twin pairs are no more similar than $\mathrm{DZ}$ twin pairs believed to be $\mathrm{DZ}$ twin pairs. ${ }^{5}$ This basic finding is impossible to explain if the environment is all that matters.

MZ twins are indeed more likely to share certain environmental experiences. They are, for example, more likely than $\mathrm{DZ}$ twins to share the same bedroom and to have the same friends but this fact in and of itself does not constitute a fatal flaw for twin studies. ${ }^{6}$ The central question is whether variable similarity on friends and bedrooms independently influences the specific trait of interest-in this case, political beliefs_-and no evidence has yet been presented that it does. In fact, empirical evidence goes further and demonstrates that the correlation between the overall frequency of twin contact and the similarity of their social and political attitudes is small and statistically insignificant. ${ }^{7}$ In terms of politics this result is not all that surprising since it seems unlikely that the parents of DZ twins are more likely than the parents of $M Z$ twins to push each of their twins in a different political direction. Compared to the parents of MZ twins, why would the parents of DZ twins be less desirous that all of their offspring share the same political beliefs?

But rather than debate what is plausible or implausible let us turn again to the empirical evidence. The most important challenge we wish to issue to Charney concerning the EEA involves the differential heritability estimates of political attitudes on the one hand and party identification on the other. Similar to previous research, ${ }^{8}$ we estimate the heritability of political and social attitudes to be in the .4 to .5 range, leaving .5 to .6 attributable to environmental factors. But these same procedures reveal that party identification is only about .14 heritable, leaving .86 attributable to the environment, so the classical twin design reports a dramatic difference in the heritability of political beliefs and party identification. Interestingly, other research identifies precisely the same pattern for religious beliefs (strong heritability) as opposed to religious denominational affiliation (minimal to no heritability). ${ }^{9}$ If violations of the EEA are responsible for reported heritability, Charney must argue that parents of $\mathrm{MZ}$ and $\mathrm{DZ}$ twins raise their children equally similarly with regard to party identification but differentially with regard to political attitudes. Why would parents of DZ twins socialize their twins to have the same party identification but different political beliefs, while parents of $M Z$ twins socialize their twins to have both similar party identifications and similar political beliefs?

Rather than merely relying on assertions, we have also empirically estimated heritability while accounting for the EEA. To do so, we have re-estimated our findings from the Virginia 30K sample using more sophisticated structural equation models that account for shared environmental influences from other family relationshipsnamely parents and non-twin siblings. ${ }^{10}$ This re-estimation with non-twin data allows us to correct for shared effects among siblings and to estimate twin-specific environment effects. The findings support our original claims that genetics accounts for at least 40 percent of the variance in ideological orientations as measured by the 28 -item WilsonPatterson index. A different approach is taken by Fowler, Baker and Dawes in their tests of the heritability of voter turnout. ${ }^{11}$ Fowler et al. test the comparability of $\mathrm{MZ}$ and $\mathrm{DZ}$ pairs on a number of politically-relevant variables and indicators of socioeconomic status. They find no mean differences between $\mathrm{MZ}$ and $\mathrm{DZ}$ pairs on these political and social variables, thus demonstrating that the traitspecific environment is simply too equal to offer any power in explaining away the heritability findings. Research in 
other areas has similarly shown either that the EEA is valid or that violations of it are too modest to negate results indicating the important influence of genes. ${ }^{12}$

Twin studies do have the potential to mislead. One of Charney's central points is that genes and the environment cannot be partitioned neatly (e.g., 14 percent genetic and 86 percent environmental) since they interact in such complicated ways. In so saying, however, Charney is only parroting a point we stressed in our original article: "Gene culture interaction is the key to understanding the source of political attitudes and behaviors, just as it is the key to understanding most physical and behavioral aspects of the human condition. Genes do not work in isolation and instead generally influence the extent to which organisms are responsive to particular environmental conditions." 13 Providing statistical estimates of the effects of genetics, shared environment, and unshared environment is not tantamount to asserting that these effects work in isolation from each other. We know of no practitioner of twin studies who believes they do. The interactions among genes and between genes and the environment create an amazingly complex situation. The good news is that, since Charney apparently believes genes and the environment interact to influence phenotypes, he must agree with us that genes are indeed behaviorally relevant.

Charney is also concerned with the fact that estimates of heritability are specific to a given population in a given environment and are therefore subject to substantial variation. This is an important point, and its import is often misunderstood, as it is by Charney. Look carefully at his example (one that can be reproduced in many other guises). He describes a study that examines the heritability of maze running ability in mice, utilizing mice selectively bred for high or low ability on this trait. As Charney describes the results:

For mice raised in a "standard" environment heritability of this trait was high. The researchers then raised the offspring of the genetically selected lines in two "extreme environments," a cognitively poor one (dull colors all around, no toys) and a cognitively enriched one (bright colors and patterns, many toys). Both the bright and dull lines behaved "stupidly" in the poor environment and "smartly" in the enriched one, with the result that the heritability of the trait dropped to zero in both extreme environments. The bright and dull mice may well have inherited whatever genes are linked to intelligence (or maze running aptitude) in mice (which is what they were bred for), but the heritability of the trait of intelligence was shown to be highly dependent upon post-natal environment. ${ }^{14}$

Several points are of critical importance here. First, notice that Charney admits to the well-established fact that the mice "may well have inherited whatever genes are linked to intelligence." Second, notice that when mice were raised in a standard environment, estimates of heritability correctly detected the significant role of genes in influencing maze-running ability. Only when mice were raised in artificially extreme environments did the apparent heritability of intelligence drop to near zero. Actual genetic inheritance continued to take place and the separate offspring of the two distinct lines would still show divergent abilities if raised in a standard environment. The extreme environments only inhibited the ability of a test of heritability to detect this continued role of genetic transmission and the direction of any bias in the estimate of heritability is conservative. In this study, extreme environments led to underestimation of the role genes play in the natural world, not to over-estimation. Far from suggesting that we should not put much faith in high estimates of heritably (such as those we found for political orientations), this example demonstrates the reverse. Studies finding zero heritability in specific environments are the ones that may be suspect, and can produce results that mask the true role of genes in the transmission of behavioral traits.

In one important area of methodology we are in full agreement with Charney. Twin studies should be seen as the beginning and not the end of research in this area and we are following this model in our own research. The twin design is typically and most profitably employed as a precursor to additional genetic work. Wet genetic techniques such as linkage analysis, which can isolate the location of genes relevant to a phenotypic behavior of interest, are best conducted with DNA drawn from close relatives such as twins. Many twin registries now have data banks containing the twins' DNA because of the value in using the same subjects to assess heritability levels and then to conduct genotyping work. Behavioral geneticists commonly move seamlessly back and forth from the twin design to bench genetics. We are currently working with several geneticists including Nicholas Martin (Laboratory Head of Genetic Epidemiology at the Queensland Institute of Medical Research in Brisbane), Lindon Eaves (Professor of Human Genetics at the Virginia Commonwealth University School of Medicine), and Shelley D. Smith (Director of Molecular Genetics at the University of Nebraska Medical Center) and have begun the process of statistically associating particular genetic alleles with political beliefs and political behaviors, a technique called allelic association.

Twin studies alone are no substitute for using linkage analysis and allelic association studies to find the specific genes contributing to the heritability of political attitudes, but searching for specific genes would be a waste of time absent evidence of heritability. With billions of nucleotide base-pairs in the nucleus of most human cells, locating the relevant individual genes is a challenging, multidisciplinary undertaking. Even when associations are found, much work remains since correlations alone will not reveal the complex pathway between genotype and phenotype. No serious scholars doubt the difficulties attending efforts to link genes to political behaviors and beliefs but we have no doubts this link will eventually be established. Additional information on the role of evolution, emotions, the 
limbic system, and neurotransmitters in shaping personal and political traits emerges every week ${ }^{15}$ and the pace is only going to pick up, making it an uncomfortable time for dualists such as Charney.

Charney writes that "Alford, Funk, and Hibbing have not discovered a set of genes corresponding to their hypothesis of genetic causation." This is quite true, we have not. But, as noted above, we are working on it. Scholars elsewhere have uncovered genes involved with reading disorders, depression, autism, risk-taking, and attention deficit hyperactivity disorder. Expecting one article to identify conclusively the specific genes and biological systems responsible for the heritability of something as complex as political beliefs is unfair. Achieving this goal will take numerous scholars working for extended periods of time in close inter-disciplinary cooperation and to say this effort should not be undertaken because it is "complicated" is both defeatist and anti-science.

\section{Political Attitudes, Orientations, and Ideologies}

Charney's critique of twin studies is predictable and largely uninformed by the state of the art in behavioral genetics, but the second half of his article provides the opportunity for an important scholarly exchange on the nature of political attitudes, political orientations, and political ideologies. Here Charney challenges our work on two grounds; first a narrow issue concerning current U.S. ideological divisions, and second a much broader conceptual critique. We will address the narrower issue first.

Charney contends that our findings from the twin study are flawed because the collection of issues in the WilsonPatterson index holds no face validity as a measure of political ideology and because they indicate the "wrong" issues as being the most heritable. Specifically, the highest heritability levels reported in our article are for property taxes, school prayer, "Moral Majority," capitalism, and astrology. Charney believes, rightly, that this is a curious collection of issues. He asserts that the highest heritability should be for abortion, gay rights, and other hot-button social issues related to sexuality and religion or that, at the very least our index of conservatism should give more weight to these issues.

Charney's concerns here are largely a moot point, however. As mentioned in our article, assortative mating is particularly powerful with regard to political and religious beliefs (conservatives mate with conservatives and liberals mate with liberals) and if parents are genetically similar then simple twin designs such as the one we employed will underestimate heritability. ${ }^{16}$ Applying the simplest possible correction for assortative mating identifies the following five issues, in order, as the most heritable:

1. Living together (.67)

2. School prayer (.66)
3. Abortion (.64)

4. X-rated movies (.63)

5. Gay rights (.60).

If Charney is correct that an acceptable test for estimating heritability of political orientations must indicate high levels of heritability for the social issues that he calls "the central concerns dividing liberals and conservatives," then the twin study findings pass this test with flying colors.

On a broader front, Charney probably speaks for a majority of political scientists in maintaining that political attitudes are socially constructed, free-standing orientations to political concepts and issues. Charney is especially taken with the context-bound nature of words such as liberal, conservative, left, and right. Since these terms are culturally rooted, he seems to conclude that any orientation to politics must be culturally rooted. He spends much of his essay recounting the history of these terms, showing that what it means to be a liberal today in the United States is not what it meant to be a liberal in France in the seventeenth century. And, of course, for much of the world, terms like "liberal" have no meaning at all. Given this, Charney asks, how is it possible that there could be a genetic basis for liberalism or any other political concept?

Our measure of political orientation consisted of an additive index of the 28 Wilson-Patterson items available to us from the Virginia $30 \mathrm{~K}$ study (contrary to Charney's claims, we used all 28 items present in the survey and did not pick some items and exclude others). We used these items as an index scored to reflect a continuum from liberal to conservative attitude positions. In choosing our language for discussing political orientation we opted for descriptors common to the field of political science, but which are probably not the most apt descriptors for the underlying phenotype. We believe that the actual underlying phenotype, whatever it is ultimately labeled, will be applicable across time and place. As such, what we have called "bedrock principles of group life" is more likely to fit the bill. The empirical evidence showing a genetic component for specific attitude positions, for example, is likely to reflect an indirect role of genetics on attitudes through the heritability of values or orientations more fundamental to living in social groups.

Recent work by Peter K. Hatemi and colleagues demonstrates that vote choice is not directly heritable but rather primarily indirectly heritable through political attitudes toward issues such as abortion, school prayer, and the death penalty. ${ }^{17}$ Up to now, detailed measures of social and political orientations have not been administered to twins (a situation we are in the process of remedying thanks to a recent grant from the National Science Foundation). When data on core preferences for social group life are available we predict they will show that attitudes toward school prayer, abortion, and the death penalty are themselves indirectly heritable and that what is directly heritable are 
orientations to bedrock principles of group life. But, of course, these ideas have yet to be tested and must be considered in comparison with alternative conceptualizations of the underlying phenotype.

We have evidence in both the U.S. and Australia for a sizeable genetic component in the transmission of political orientations but this is not yet enough to claim with confidence that these findings are applicable across all cultures and contexts. Regardless, we do not agree with Charney's unsubstantiated assertion that culture universals do not exist. Schwartz and Bardi's recent cross-cultural study of values more realistically captures the situation:

Studies at the national level reveal a great deal of variation in the value priorities of individuals within societies as well as groups across nations. The research suggests that individuals both within and across societies have quite different value priorities that reflect their different genetic heritage, personal experiences, social locations, and enculturation. Yet hidden behind these important differences is a surprise that may reflect something about the origins and role of values for human society. Researchers, including ourselves, have focused almost exclusively on differences in value priorities. When we switch our focus to ask about similarities, we discover a striking degree of consensus across individuals and societies ... Differences are more salient and compelling than similarities. It may therefore be difficult to accept that a largely shared, pan-cultural value hierarchy lies hidden behind the striking value differences that draw our attention. Differences help us to identify the influences of unique genetic heritage, personal experience, social structure, and culture on value priorities. The pan-cultural hierarchy points to the bases of values in shared human nature and to the adaptive functions of values in maintaining societies. To gain a full understanding of human value priorities, we must take note of the interplay of both differences and similarities. ${ }^{18}$

Charney rightly raises the critical question of just how genes could influence political beliefs. Numerous possibilities exist. The connection could run through personality; it could run through temperaments such as risk-taking, fear, and preference for structure and certainty; it could run through a tendency to hold beliefs intensely or casually; or it could even run through genetically-based physical traits, as Charney speculates. There are endless possibilities and we do not pretend to know the actual mechanisms. This is what we are investigating now. As mentioned above, our collaborative research with the goal of associating particular genetic alleles with particular political beliefs and behaviors will move us down that path. But it will be a long and difficult process, requiring collaborative efforts among scholars with an open mind and a healthy respect for the scientific process of testing and revising hypotheses based on empirical observation.

Led by numerous social scientists including Jost, Haidt, and Thornhill, there is growing support for seeing political ideology as springing from deeper, seemingly non-political traits. ${ }^{19}$ Of course, researchers have long noted the connection between personality and politics and the evidence is rapidly building that political ideology is intimately con- nected with other aspects of temperament. ${ }^{20}$ For example, compared to liberals, political conservatives have fundamentally different approaches to child-rearing. ${ }^{21}$ Our own recent analysis finds that a simple four-item strict parenting scale is strongly correlated with the Wilson-Patterson index $(r=.45 ; \mathrm{p}<.001)$. Similarly, people who say "good manners and cleanliness matter" are more likely to be politically conservative (gamma $=.32 ; \mathrm{p}<.001$ ) and people who "would take drugs that may have strange effects" are more likely to be politically liberal (gamma $=.48 ; \mathrm{p}<.001){ }^{22}$ The brains of conservatives react differently, on average, from the brains of liberals to an unexpected (but completely nonpolitical) stimulus. ${ }^{23}$ And it is possible to make accurate predictions of the political beliefs of adults on the basis of the observed (not self-reported) social behaviors of those same individuals at nursery school twenty years previously. ${ }^{24}$ In sum, people vary dramatically in their orientation toward order, threat, risk, uncertainty, and obedience to traditional values and these variations in turn are statistically related to political attitudes and ideology. Ideology is connected to foundational preferences for social and political structure and these preferences likely have a basis in neurotransmitters, brain activity, and ultimately genetics.

We have hopes that raising the possibility that politics is partially heritable will encourage a much needed reconsideration of the nature of political temperament. The discipline would benefit from trying new research methods and from viewing political ideologies as something other than completely "context dependent." In our view, if genes shape politics, the connection does not run through the musings of nineteenth- and twentiethcentury political theorists but rather through the core principals of social life as they have existed since before we were fully human.

\section{Conclusion}

No scientifically literate person in this day and age can claim that genes are irrelevant to human behavior and predispositions, yet many people are deeply discomfited by this reality. One common solution is to concede that genes affect behavior, but to assert that the connection is extraordinarily complex and then to proceed as if this complexity negated any requirement that we incorporate this sometimes uncomfortable reality into research into, and understanding of, human behavior. This is where we part company. To us, the reality of a complex link between genes and political phenotypes means political scientists must rein in their reflexive environmentalism and join forces with behavioral geneticists and others in the biological community to continue the exacting, time-consuming, but deeply exciting genetic research that has already begun the process of teasing out this complexity.

We never claimed that a focus that incorporates genes obviates the need to also consider the environment. Indeed, 
casting the issue as genes competing with the environment, as Charney does in his conclusion ("if genes count for more than environment the phenomena of liberalism and conservatism ... become utterly incomprehensible") is silly and misses the point. What we claim is that genes are important to political thought and behavior. We realize that for a discipline as completely vested in nurture alone as political science, the need to look at both nurture and nature will constitute an important shift. As Charney puts it:

The claim of Alford, Funk, and Hibbing is indeed astonishing, because if true, it would require nothing less than a revision of our understanding of all of human history, much, if not most of political science, sociology, anthropology, and psychology, as well as, perhaps, our understanding of what it means to be human. ${ }^{25}$

The "claim" is of course not wholly ours, but more appropriately the claim of over twenty years of behavioral geneticists who pioneered research in this area. But we are in complete agreement with what is at stake. Our 2005 article found a substantial degree of heritability for political orientations, but political behavior subtends far more than political orientations and the study of genetic influences does not end with a single classical twin study. Geneticists can only go so far in their investigation of a field as foreign to them as political behavior. Political scientists need to engage if genetic research in this area is to progress beyond rudimentary dependent variables and if political science is going to progress beyond a narrowly limited set of environmental independent variables. Colleagues from across the social and natural sciences are currently conducting research on large-scale human social cooperation that is among the most exciting and challenging scientific revolutions of our times. With political scientists largely isolated from this effort, it is no surprise that researchers from other fields have mostly missed the point that largescale human cooperation is politics, not just neuroeconomics or evolutionary psychology. We can right this wrong if, and only if, we join with our colleagues from across the sciences in this grand search.

\section{Notes}

1 Alford, Funk, and Hibbing 2005.

2 Charney 2008.

3 Horwitz et al. 2003, 113-14.

4 O'Connor et al. 1998.

5 Scarr and Carter-Saltzman 1979; Plomin 1990;

Kendler et al. 1993; Hatemi 2007.

6 Scarr and Carter-Saltzman 1979; Kendler et al. 1992.

7 Martin et al. 1986.

8 Ibid.

9 Bouchard and McGue 2003.

10 Hatemi et al. 2007b.

11 Fowler, Baker, and Dawes 2006.
12 E.g., Plomin et al. 1976; Morris-Yates et al. 1990; Kendler et al., 1993; Xian et al. 2000; Cronk et al. 2002; Eriksson et al. 2006.

13 Alford, Funk, and Hibbing 2005: 165.

14 Charney 2008, 300-1.

15 Madsen 1986; Marcus, Neuman, and MacKuen 2000; Orbell et al. 2004; McDermott 2004; Schreiber 2005; Lodge and Taber 2005; Westen et al. 2006; Alford and Hibbing 2007; Carmen 2007.

16 Hatemi et al. 2007b.

17 Hatemi et al. 2007a.

18 Schwartz and Bardi 2001.

19 Jost 2006; Jost et al. 2003; Haidt and Graham 2008; Thornhill and Fischer 2007.

20 Adorno et al. 1950; McClosky 1958.

21 For an early example see Laswell 1930, or more recently Lakoff 2002.

22 Alford and Hibbing 2007.

23 Amodio, Jost, Master, and Yee 2007.

24 Block and Block 2005.

25 Charney 2008, 300.

\section{References}

Adorno, T., E. Frenkel-Brunswik, D. Levinson, and R. Sanford. 1950. The Authoritarian Personality. New York: Harper.

Alford, John R., Carolyn L. Funk, and John R. Hibbing. 2005. Are political orientations genetically transmitted? American Political Science Review 99 (2): 153-68.

Alford, John R., and John R. Hibbing. 2007. Personal, inter-personal, and political temperaments. Annals of the Academy of Political and Social Science 614 (November): 196-212.

Amodio, David M., John T. Jost, Sarah L. Master, and Cindy M. Yee. 2007. Neurocognitive correlates of liberalism and conservatism. Nature Neuroscience 10: 1246-7.

Block, Jack, and Jeanne H. Block. 2005. Nursery school personality and political orientation two decades later. Journal of Research in Personality 39: 395-422.

Bouchard, T.J., Jr., and Matt McGue. 2003. Genetic and environmental influences on human psychological differences. Journal of Neurobiology 54: 4-45.

Carey, Gregory. 2003. Human Genetics for the Social Sciences. Los Angeles, CA: Sage Publications.

Carmen, Ira H. 2007. "From Genes to Mind to Politics." Presented at the annual meeting of the Midwest Political Science Association, Chicago, April 12-15.

Charney, Evan. 2008. Genes and ideologies. Perspectives on Politics 6 (2): 299-315.

Cronk, N.J., W.S. Slutske, P.A. Madden, K.K Bucholz, W Reich, and A.C. Heath. 2002. Emotional and 
behavioral problems among female twins: An evaluation of the equal environments assumption. Journal of the American Academy of Child and Adolescent Psychiatry 41: 829-37.

Eriksson, Marit, Finn Rasmussen, and Per Tynelius. 2006. Genetic factors in physical activity and the equal environment assumption: The Swedish young male twins study. Behavior Genetics 36: 238-47.

Fowler, James H., Laura Baker, and Christopher T. Dawes. 2006. "The Genetic Basis of Political Cooperation." Presented at the annual meeting of the American Political Science Association, Philadelphia, PA, August 30-September 2.

Gerring, John 1997. Ideology: A definitional analysis. Political Research Quarterly 50: 957-94.

Gosling, Samuel D., and Oliver P. John. 1999. Personality dimensions in non-human animals: A cross-species review. Current Directions in Psychological Science 8: 69-75.

Haidt, Jonathan, and Jesse Graham. 2008. "When Morality Opposes Justice: Conservatives Have Moral Intuitions that Liberals May Not Recognize." Social Justice Research 21, forthcoming.

Hatemi, Peter K. 2007. "The Genetics of Political Attitudes.” PhD Diss., University of Nebraska-Lincoln.

Hatemi, Peter K., Sarah E. Medland, Kate I. Morley, Anthony C. Heath, and Nicholas G. Martin. 2007a. The genetics of voting: An Australian twin study. Behavior Genetics 37: 435-48.

Hatemi, Peter K., John R. Alford, John R. Hibbing, Nicholas G. Martin, and Lindon J. Eaves. 2007b. "Not by Twins Alone: Using the Extended Twin Family Design to Investigate the Genetic Basis of Political Beliefs." Presented at the annual meeting of the Midwest Political Science Association, Chicago, April 12-15.

Horwitz, Allan, Tami Videon, Mark Schmitz, and Diane Davis. 2003. Rethinking twins and environments: Possible social sources for assumed genetic influences in twin research. Journal of Health and Social Behavior 44: 111-29.

Jost, John T. 2006. The end of the end of ideology. American Psychologist 61: 651-70.

Jost, John T., Jack Glaser, Arie W. Kruglanski, and Frank J. Sulloway. 2003. Political conservatism as motivated social cognition. Psychological Bulletin 129: 339-75.

Kendler, Kenneth S., Michael C. Neale, R.C. Kessler, Andrew C. Heath, and L.J. Eaves. 1992. A population based twin study of major depression in women: The impact of varying definitions of illness. Archives of General Psychiatry 49: 257-66.

-1993. A test of the equal environment assumption in twin studies of psychiatric illness. Behavior Genetics 23: 21-27.
Lakoff, George. 2002. Moral Politics: How Liberals and Conservatives Think. Chicago: University of Chicago Press.

Laswell, Harold. 1930. Psychopathology and Politics. Chicago: University of Chicago Press.

Lodge, Milton, and Charles S. Taber. 2005. The automaticity of affect for political leaders, groups, and issues. Political Psychology 26: 455-82.

Madsen, Douglas. 1986. Power seekers are different. American Political Science Review 80 (1): 261-69.

Marcus, George E., W.R. Neuman, and Michael MacKuen. 2000. Affective Intelligence and Political Judgment. Chicago: University of Chicago Press.

Martin, N.G., L.J. Eaves, A.C. Heath, R. Jardine, L.M. Feingold, and H.J. Eysenck. 1986. Transmission of social attitudes. Proceedings of the National Academy of Sciences (15 June): 4364-68.

McClosky, Herbert. 1958. Conservatism and personality. American Political Science Review 52 (1): 27-45.

McDermott, Rose. 2004. The feeling of rationality: The meaning of neuroscientific advances for political science. Perspectives on Politics 2 (4): 691-706.

Morris-Yates, A., G. Andrews, P. Howie, and S. Henderson. 1990. Twins: A test of the equal environments assumption. Acta Psychiatrica Scandinavica 81 (4): 322-6.

O'Connor, T.G., K. Deater-Deckard; D Fulker, M. Rutter, and R. Plomin. 1998. Genotype-environment correlations in late childhood and early adolescence: Antisocial behavior problems and coercive parenting. Developmental Psychology 34 (5): 970-81.

Orbell, John, Tomonori Morikawa, Jason Hartwig, James Hanley, and Nicholas Allen. 2004. Machiavellian intelligence as a basis for the evolution of cooperative dispositions. American Political Science Review 98 (1): 1-16.

Plomin, R. 1990. The role of inheritance in behavior. Science, 183-248, April 13.

Plomin, R., J.C. DeFries, G.E. McClearn, and P. McGuffin. 2001. Behavioral Genetics, 4th ed. New York: Worth.

Plomin, R., L. Willerman, and J.C. Loehlin. 1976. Resemblance in appearance and the equal environments assumption in twin studies of personality traits. Behavior Genetics 6: 43-52.

Scarr, Sandra, and L. Carter-Saltzman. 1979. Twin method: Defense of a critical assumption. Behavior Genetics 9: 527-42.

Schreiber, Darren. 2005. "Evaluating Politics: A Search for the Neural Substrates of Political Thought." PhD diss., UCLA, Los Angeles, CA.

Schwartz, S. H., and A. Bardi. 2001. Value hierarchies across cultures: Taking a similarities perspective. Journal of Cross Cultural Psychology 32: 268-90. 
Thornhill, Randy, and Corey L. Fischer. 2007. "What Is the Relevance of Attachment and Life History to Political Values?" Presented at the annual meeting of the Human Behavior and Evolution Society, Williamsburg, VA, May 30-June 3.

Westen, D., P. Blagov, K. Harenski, C. Kilts, and S. Hamann. 2006. Neural basis of motivated reasoning: An fMRI study of emotional constraints on political judgment during the U.S. presidential election of 2004. Journal of Cognitive Neuroscience 18: 1947-58. Xian, H., J.F. Scherrer, S.A. Eisen, W.R. True, A.C. Heath, J. Goldberg, M.J. Lyons, and M.T. Tsuang. 2000. Self-reported zygosity and the equal environments assumption for psychiatric disorders in the Vietnam era twin registry. Behavior Genetics 30: 303-10. 